\title{
Forest buffalo prefer clearings to closed-canopy forest in the primary forest of northern Congo
}

\author{
Stephen Blake
}

\begin{abstract}
During 1993-2000 the conservation status of forest buffalo Syncerus caffer was investigated in the Nouabalé-Ndoki National Park region, northern Congo. Data from dung counts collected during a number of ecological reconnaissance surveys in and around the National Park showed that the preferred buffalo habitat was open canopy swamps and forest clearings associated with watercourses. Buffalo abundance was very low in terra firma forest more than $250 \mathrm{~m}$ from water, and signs were restricted to large elephant trails connecting watercourses and clearings. The clumped distribution of the buffalo appeared to be a result of the highly patchy
\end{abstract}

distribution of their food resources. In terra firma forest preferred food species were poorly represented, whereas in open swamp and sedge clearings they were more abundant. Low overall numbers, highly patchy distribution, small group size, and low effort-high return for hunters, including sport hunters, mean that buffalo must be considered a conservation priority in this environment.

Keywords Congo, forest buffalo, habitat requirements, Nouabalé-Ndoki National Park, primary forest, Syncerus caffer.

\section{Introduction}

The African buffalo Syncerus caffer is the largest of the African bovids. There is one generally recognised species in Africa, Syncerus caffer (Grubb, 1972), although phenotypic characteristics vary considerably across the continent. There is some confusion over the taxonomy of possible subspecies (Sinclair, 1977; Prins, 1996), and at least two subspecies occur (Grubb, 1972); the cape buffalo, Syncerus caffer caffer of eastern and southern African savannahs, and the forest buffalo, Syncerus caffer nanus which inhabits the forests of west Africa (Dorst \& Dandelot, 1972). Buffalo in the Central African forests, S. c. brachyceros (Grubb, 1972), may be an intermediate form between S. c. caffer and S. c. nanus. The cape buffalo is the largest of the subspecies with males weighing up to $850 \mathrm{~kg}$ (Kingdon, 1997), and there is sexual dimorphism, although less marked than in most bovids. On average, the forest subspecies weighs approximately half that of the cape buffalo (Estes, 1991).

The cape buffalo has been extensively studied, and its ecology and social organisation are well known (Blancou, 1958; Sinclair, 1977; Prins, 1996). Basic social organisation consists of stable groups of cows, with

Stephen Blake Nouabalé-Ndoki Project, International Programs, The Wildlife Conservation Society, 185th Street and Southern Boulevard, Bronx, 10460, New York, USA, and Institute of Cell, Animal, and Population Biology, University of Edinburgh, King's Buildings, West Mains Road, Edinburgh. EH9 3JT, UK. E-mail: steveblake@worldnet.att.net

Received 6 June 2000. Revision requested 7 November 2000 Accepted 14 September 2001 associated offspring often in sub-groups, and a number of sub-adult and adult males. Group size may vary from less than 20 to more than 1,000 individuals (Sinclair, 1977; Estes, 1991; Prins, 1996). Both sexes exhibit a social dominance hierarchy (Estes, 1991). Breeding males may be semi-nomadic, and remain only loosely associated with female herds (Sinclair, 1977; Prins, 1996). Cape buffalo are primarily grazers, but a portion of the diet is also made up of browse, which may become increasingly important during the dry season (Prins, 1996). Biomass is highest in savannah-woodland mosaics, and buffalo can reach extremely high densities, up to $20 \mathrm{~km}^{-2}$ (Prins, 1996). Cape buffalo need to drink daily because they cannot obtain sufficient liquid from their diet, and consequently they are usually found close to water (Western, 1975; Sinclair, 1977; Prins, 1996). By contrast the forest buffalo remains poorly known. In his summary of the ecology of the sub species, Kingdon (1997) states that "The forest buffalo depends on low level browse and an undetermined minimum of grass in its diet, limiting it to grassy glades, watercourses, and waterlogged basins". Forest buffalo live in small, stable groups of cows and offspring with one or more resident adult males (Kingdon, 1997).

The cape buffalo is widespread throughout Africa and is categorised as Lower Risk, Conservation Dependent on the 2000 IUCN Red List (Hilton-Taylor, 2000), even though numbers remain high in many areas. However, there are few estimates of the distribution and abundance of the forest buffalo, and so evaluation of the conservation status of the subspecies is difficult. White (1992) estimated a maximum density of 0.42 buffalo per 
$\mathrm{km}^{2}$ at a single site in the Lope Reserve, Gabon, where the vegetation was characterised by a savannah-forest mosaic and forests with high densities of ground rooted monocotyledons, particularly species of Marantaceae. Out of five forested sites studied at Lope, buffalo densities were highest at those sites in proximity to open savannah (White, 1992). In open savannah at Lope, density was estimated as 4.3 buffalo per $\mathrm{km}^{2}$ (Molloy, 1997). In the Odzala National Park of north central Congo buffalo were concentrated in savannahs and near to marshy clearings known as bais (Chamberlan et al., 1995; Maisels, 1996; Vanleeuwe et al., 1998), although density and distribution patterns remain unknown. In a matrix of forest, swamp and savannah in western Gabon, Prins \& Reitsma (1989) found no evidence of buffalo in primary forest, although they were present in both savannahs and secondary forest

This paper presents data on the distribution and relative abundance of forest buffalo from a large, intact forest site in northern Republic of Congo. Preliminary information on food selection is also provided. Buffalo distribution was highly localised near to open swampy meadows, which provided an abundance of preferred plant food species, while the majority of the terra firma forest more than c. $250 \mathrm{~m}$ from water appeared to be unsuitable habitat and was seldom visited by buffalo. Thus only a small fraction of the total forest cover, and of the protected area at this site, can be considered to be suitable habitat for the forest buffalo.

\section{Study site}

The Nouabalé-Ndoki National Park (NNNP) was created in 1993 in northern Republic of Congo and covers an area of $c .4,000 \mathrm{~km}^{2}$ of moist tropical lowland forest that has never been commercially logged. Described by Rollet (1964) and Letousey (1968) as Sterculiaceae-Ulmaceae semi-deciduous forest, the vegetation of the region is characterised by mixed species terra firma forest with a moderately open canopy, swamp forests often dominated by Raphia spp. (Arecaceae), and Gilbertiodendron dewevrei forest, which is found in both riverine and upland habitats and covers c. $25 \%$ of the park surface area (Blake \& Fay, 1997; NNP, 2001). Forest clearings, which may be created and maintained by the activity of large mammals, particularly elephants (Turkalo \& Fay, 1995), are a characteristic feature of the Park. These clearings are dominated by sedges (Cyperaceae spp.) and grasses (Poaceae spp.), similar to forest clearings described in the Democratic Republic of Congo (Léonard, 1951).

The large mammal fauna of the region includes forest elephants Loxodonta africana cyclotis, western lowland gorillas Gorilla gorilla gorilla, chimpanzees Pan troglodytes troglodytes, forest buffalo, bongo Tragelaphus euryceros, sitatunga Tragelophus spekii, two species of Suidae, six species of duiker (Cephalophus spp.), and nine species of diurnal monkeys (Colobus spp., Cercopithecus spp., Cercocebus spp. and Allenopithecus nigroviridis). There are no permanent human habitations inside the park and the surrounding population density is extremely low $\left(<1\right.$ inhabitant per $\left.\mathrm{km}^{2}\right)(\mathrm{NNP}, 2001)$. The nearest village (Bomassa, with c. 200 inhabitants) is $20 \mathrm{~km}$ from the park border. Human impact on the forest ecosystem has been low, and mammal populations remain largely intact. There was intense elephant poaching in several key areas of the park in the 1980s, particularly to the north-west, the northern border, and the south-west. Buffalo hunting was generally low and is now absent within the Park. Hunting within the park was reduced to negligible levels with the implementation of the Nouabalé-Ndoki Forest Conservation Project (NNP) in 1991.

\section{Methods}

I carried out ecological reconnaissance surveys, with the help of variable numbers of trackers, throughout the national park and the surrounding region from 1993-2000. These surveys were designed to provide a rapid assessment of the relative abundance of large mammals, and human incursions and their impact, to provide data for management of the park. Of these surveys, only those conducted in areas where human impact was considered to have a negligible impact on buffalo distribution and abundance are presented here.

Surveys were conducted on foot using three different methods. (1) A 'path of least resistance' (PLR) track on a general compass bearing through the forest (Walsh \& White, 1999). Routes were planned to pass through areas where information was scarce, or across gradients in vegetation or human activity. Deviations from the desired bearing were occasionally made for features of interest, such as large elephant trails or fresh signs of human activity. (2) Straight line transects following the 'short-cut method' (SCM) of Barnes \& Jensen (1987). The frequency of animal signs per kilometre walked was used as an index of animal abundance rather than more complex analyses of line transect data (e.g. Buckland, 1993). (3) Recce surveys (RECCE) which attempted to follow a straight line but permitted deviations of up to 40 degrees from the straight line to avoid obstacles, such as tree falls and thickets (Walsh \& White, 1999). For the purposes of this paper, which are to present general trends in buffalo distribution rather than density estimates, data from these methods are compatible and have therefore been combined.

Change in vegetation type, based on general characteristics of structure and composition, was recorded with distance along the survey track. All signs of buffalo, 
including direct observations, vocalisations, dung piles and fresh feeding activity, seen from the survey track were recorded with distance along the track. Only those feeding signs associated with other positively identifiable buffalo signs, such as tracks or dung, were recorded. Tracks, the visibility of which varies greatly with substrate (e.g. soft mud versus compacted dry soil), were not individually counted, but their presence was noted. All dung piles were assigned a crude age classification of fresh ( $<24$ hours), recent ( $1-5$ days), old (5-15 days) and very old ( $>15$ days). Fresh dung was still liquid or had a thin dry crust with liquid beneath, recent dung had a thicker crust and was clearly drying but still had some liquid, old dung was dry and beginning to break up, and very old dung was in an advanced state of decay, heavily fragmented and beginning to disappear. A dung decay study was not conducted, and duration in days was estimated from ad lib observations. No attempt was made to calculate buffalo density from dung counts because, unlike straight line transects, path of least resistance surveys introduce bias into dung density estimates (Walsh \& White, 1999). Even if the bias could have been estimated (Walsh \& White, 1999), it was considered that extrapolating published data on defecation rates and dung decay to this study site would not provide a reliable estimate of buffalo density.

\section{Results}

Summary data from 10 survey routes are shown in Table 1. Survey routes were divided into two strata, riverine and upland, which were within or more than $250 \mathrm{~m}$ from watercourses or clearings respectively.
Most surveys used GPS data, accurate to $c .100 \mathrm{~m}$, and 1:200,000 scale maps (the best available for the region), which meant that spatial resolution on larger scales was inaccurate.

Buffalo abundance was very clearly associated with watercourses and forest clearings. A total distance of $3,025 \mathrm{~km}$ of foot surveys was covered during the 10 surveys. Of the total distance covered, $1,197 \mathrm{~km}$ was more than $250 \mathrm{~m}$ from water (40\%). Thirty-nine buffalo dung piles were recorded in this upland stratum while 2,126 were recorded in the riverine stratum. This difference in buffalo dung density between the two strata was highly significant (Mann-Whitney, $U=8.00, P<0.001$, $n=10$ ). All of the dung and other signs of buffalo seen in the upland stratum were on large elephant trails connecting watercourses or clearings, suggesting that buffalo use uplands to traverse between these lowland habitats.

Within the riverine stratum, buffalo dung abundance was highest in proximity to open swamp vegetation and clearings. Considering PLR7 alone, $70 \%$ of the total dung was recorded in only $20 \%$ of the total distance covered in the riverine stratum, indicated by the rectangle in Fig. 1.

Few data were collected on forest buffalo feeding ecology because direct observations were difficult under forest conditions, although secondary feeding signs gave a broad indication of preferences. Poaceae of many species are probably the dominant feature of the diet and, when the buffalo were observed feeding in bais, grazing (or ruminating) was the most common activity. Sedges (Cyperaceae), particularly the tips of Rhyncospora corymbosa, Kyllinga spp. and Cyperus spp., were also

Table 1 Summary data of buffalo surveys and relative buffalo dung abundance.

\begin{tabular}{|c|c|c|c|c|c|c|c|c|}
\hline \multirow[b]{2}{*}{$\begin{array}{l}\text { Survey } \\
\text { method }\end{array}$} & \multirow[b]{2}{*}{ Date } & \multirow[b]{2}{*}{$\begin{array}{l}\text { Total survey } \\
\text { distance }(\mathrm{km})\end{array}$} & \multicolumn{3}{|c|}{ 'Upland' strata ( $>250 \mathrm{~m}$ from water) } & \multicolumn{3}{|c|}{ 'Riverine' strata ( $<250 \mathrm{~m}$ from water) } \\
\hline & & & $\begin{array}{l}\text { Length of } \\
\text { survey }\end{array}$ & $\begin{array}{l}\text { No. dung } \\
\text { piles }\end{array}$ & $\begin{array}{l}\text { Dung piles } \\
\text { per } \mathrm{km}\end{array}$ & $\begin{array}{l}\text { Length of } \\
\text { survey }\end{array}$ & $\begin{array}{l}\text { No. dung } \\
\text { piles }\end{array}$ & $\begin{array}{l}\text { Dung piles } \\
\text { per } \mathrm{km}\end{array}$ \\
\hline SCM1 & Dec 1993 & 75.0 & 45.9 & 0 & 0.00 & 29.1 & 3 & 0.10 \\
\hline PLR1 & Mar 1994 & 247.0 & 152.0 & 0 & 0.00 & 95.0 & 10 & 0.11 \\
\hline PLR2 & Jan 1996 & 125.0 & 101.4 & 0 & 0.00 & 23.6 & 2 & 0.08 \\
\hline PLR3 & Mar 1996 & 53.1 & 23.3 & 0 & 0.00 & 29.8 & 0 & 0.00 \\
\hline RECCE1 & Nov 1997 & 145.0 & 42.5 & 2 & 0.05 & 102.5 & 84 & 0.82 \\
\hline PLR4 & Feb 1998 & 95.0 & 49.3 & 3 & 0.06 & 45.8 & 5 & 0.11 \\
\hline PLR5 & Apr 1998 & 25.0 & 0.0 & 0 & 0.00 & 25.0 & 244 & 9.76 \\
\hline RECCE2 & Oct 1999 & 90.0 & 52.7 & 0 & 0.00 & 37.3 & 3 & 0.08 \\
\hline PLR6 & Oct 1999 & 145.0 & 21.0 & 0 & 0.00 & 124.0 & 545 & 4.40 \\
\hline PLR7* & 1998-2000 & 225.0 & 78.8 & 3.8 & 0.05 & 146.2 & 136.7 & 0.9 \\
\hline Total & & 1225.1 & 566.9 & 8.8 & & 658.3 & 1032.7 & \\
\hline Mean & & & & & 0.02 & & & 1.64 \\
\hline
\end{tabular}

* this survey route has been completed nine times over the last two years (in March, June, September and December of each year), data are mean dung counts for all surveys.

$\mathrm{PLR}=$ Past of least resistance surveys, $\mathrm{SCM}=$ Short-cut method transects, $\mathrm{RECCE}=$ Recce surveys. 


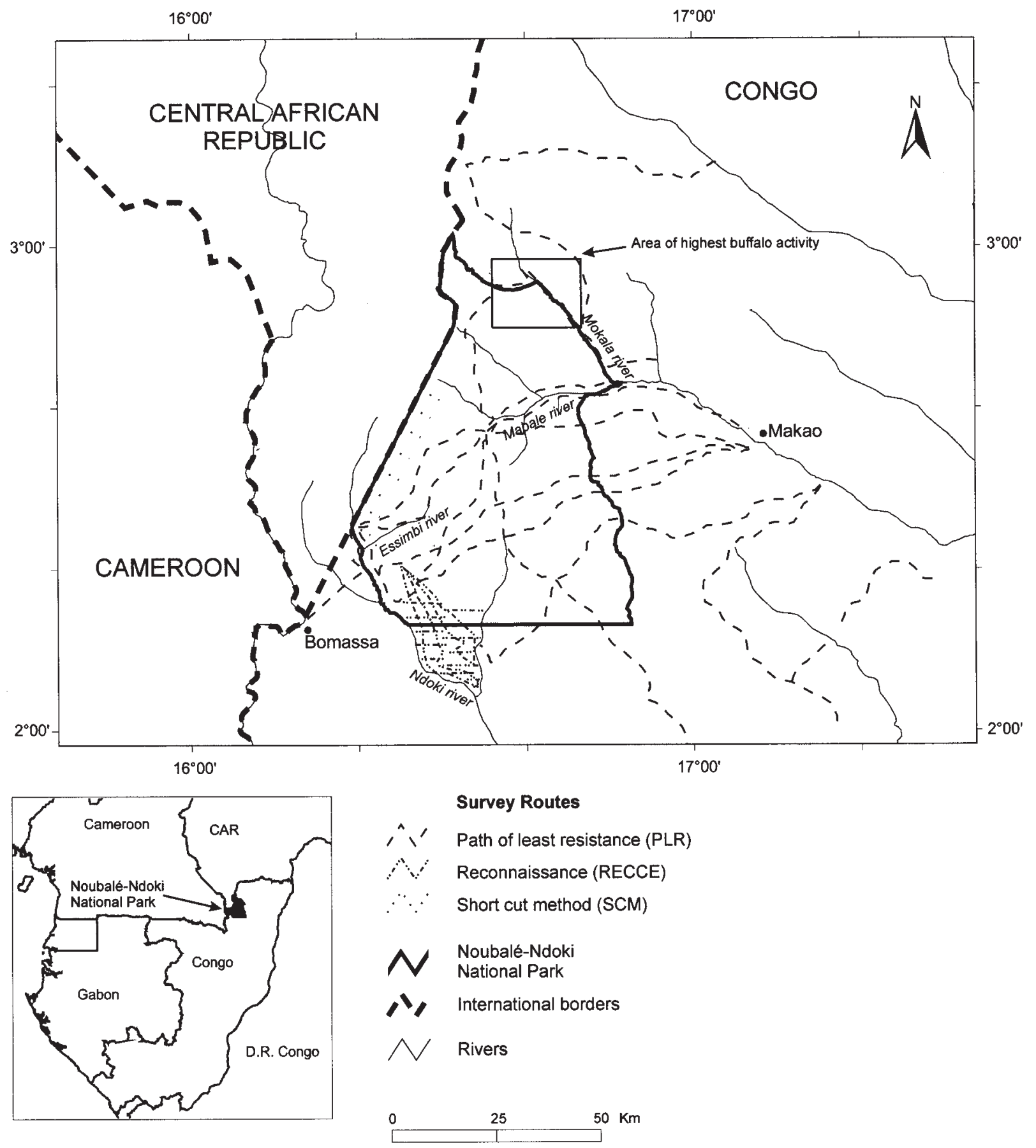

Fig. 1 Map of the Nouabalé-Ndoki National Park region showing survey routes, rivers and the area of intense buffalo activity.

eaten. Other monocotyledons that appeared to have been eaten by buffalo included several species of Marantaceae, notably those that grow on marshy or saturated soils, such as Marantochloa purpurea, M. cordifolia, Halopegia azurea, and $M$. filipes on terra firma. The leaf blades and upper stems were preferred for consumption. Feeding signs on several species of Commelinaceae were also recorded, particularly the semi-aquatic Commelina diffusa, and Palisota brachythyrsa, which dominates the understorey in mono-dominant $G$. dewevrei forest. These species (with the exception of $P$. brachythyrsa) are often abundant in marshy light gaps, and almost never occur in closed canopy swamps or terra firma forests (Blake, unpub. data). A species of algae (Spirogyra sp.) was eaten when available although it is rare and restricted to shallow forest lakes. 


\section{Discussion}

The data presented here show that, like savannah buffalo, forest buffalo in the Nouabalé-Ndoki National Park region are highly concentrated near to watercourses. Buffalo dung frequency was two orders of magnitude lower in the upland stratum compared to the lowland stratum. Seventy nine percent $\left(3,045 \mathrm{~km}^{2}\right)$ of the surface area of the national park is in the upland stratum. Of the remaining $21 \%$ in the lowland stratum, buffalo abundance was further clumped in proximity to open grassy and sedge meadows. Buffalo were found therefore in only a tiny fraction of the forest potentially available to them.

The most likely determinant of buffalo abundance appeared to be not simply water but the presence of grass and sedge dominated clearings, which were correlated with standing water. The swamp adjacent to the Mokala River within the area of maximum buffalo sign abundance (Fig. 1) was characterised by an open canopy with frequent large, open swampy clearings dominated by grasses and sedges. To the north and south of this region, where buffalo sign frequency was reduced, the swamp forests had relatively closed canopies dominated by large and medium sized trees such as Alstonia congensis, Mitragyna stipulosa and Lasiodiscus sp.. The open swampy vegetation types were also well represented on the Essimbi and the Mabale Rivers (Fig. 1) and here too buffalo abundance was particularly high. By contrast, the swamps of the lower Ndoki River south of the Park had a largely closed canopy and the frequency of buffalo signs was low.

Long term observations at two major clearings (Dzanga and Mbeli, 10 and 6 years respectively) in the region indicate that each is used by only a single stable group of buffalo (A. Turkalo, R. Parnell \& D. Morgan, pers. comm.). Observations from Odzala National Park, also in Congo, support the single group occupancy of clearings (Maisels, 1996; Mbolo, pers. comm.). Clearings are rare, discrete patches in the forest, which offer abundant quantities of favoured foods compared to forest habitats. Why then should each be exploited by only a single group? Two possible explanations seem likely; either buffalo numbers are extremely low and only a single group occupies the forest containing the clearing, or they have almost exclusive home ranges, and those herds that occupy high quality home ranges containing clearings defend them successfully. Given the generally non-aggressive behaviour of savannah buffalo (Sinclair, 1977) the latter explanation seems unlikely. However, there are considerable differences in ecology between savannah and forest buffalo, which may lead to differences in social organisation and competition for resources. This study has shown that buffalo preferentially occupy patches of very high quality in a generally poor quality forest habitat. Savannah habitats are also patchy but less so than forests and food resources are more generally available (e.g. Sinclair, 1977). Forest buffalo may experience higher intra-specific feeding competition, which would favour small herd size and defence of resources (e.g. Crook, 1970; Weins, 1977). Unlike savannah buffalo, male forest buffalo are apparently permanent group members (Kingdon, 1997; Turkalo \& Parnell, pers. comm.; Blake, pers. obs.), which may also imply social organisation directed toward defence of resources.

These data have shown that the majority of closed canopy forest available in the Ndoki forest is unsuitable for forest buffalo, probably because of limited feeding opportunities. The overall abundance of buffalo signs in the forest was extremely low. Out of the $3,860 \mathrm{~km}^{2}$ covered by the Nouabalé-Ndoki National Park, less than $20 \%$ (probably closer to $5-10 \%$ or $193-386 \mathrm{~km}^{2}$ ) appears to be used by buffalo. Effective conservation of forest buffalo in primary forest therefore appears to require the protection of very large areas because the availability of these patchy habitats is low and they are widely dispersed. While there is no information on forest buffalo dispersal, protection of high quality patches alone would almost certainly lead to fragmentation of the buffalo population if dispersal between patches became impossible.

The high relative abundance and visibility of buffalo in clearings and open swamp make them easy targets for poachers. Clearings may often provide the only source of high quality forage in a considerable area and so buffalo are probably forced to return to them to feed despite the potential danger.

In a number of areas in Central Africa forest buffalo are exploited through safari hunting. In Congo, bongo, rather than buffalo, are currently the animal of choice for may sport hunters interested in forest hunting safaris, although forest buffalo are also readily taken. Bongo hunting is temporarily banned in Congo because very little is known about the ecology and population dynamics of the species. There is thus a tendency to promote buffalo hunting as a substitute because it is widely assumed that buffalo are abundant and less threatened by over-hunting. This paper has shown that in primary forest this assumption is unjustified, and a greater ecological understanding of forest buffalo is needed before rational management options regarding sport hunting can be developed. With low overall numbers, little idea of true densities across habitat types, highly patchy distribution, adult bulls (the target of sport hunters) showing a high degree of social fidelity, and low effort-high return for poachers, buffalo must be considered a conservation priority in this environment. 


\section{Acknowledgements}

The Government of Congo made the NNNP a reality. Mr Le Ministre de l'Economie Forestier, Henri Djombo et Prof. A. Itoua-Ngaporo, Delegue Generale de la Recherche Scientifique are thanked for permission to conduct this study. The Nouabalé-Ndoki Project thanks USAID, CARPE, PROGECAP and WCS for providing funding. The United States Fish and Wildlife Service, Save the Elephants, Columbus Zoo, PROGECAP and WCS are thanked for funding specific components of fieldwork that went into this paper. The author thanks Mike Fay, Richard Ruggiero, Yves Djoni-Bourgess and Bryan Curran for facilitating fieldwork, and Dr. Fiona Maisels for useful comments. Kate Abernathey and two anonymous reviewers are thanked for very useful criticisms of earlier drafts.

\section{References}

Barnes, R.F.W. \& Jensen, K. (1987) How to count elephants in forests. Technical Bulletin of African Elephant and Rhino Specialist Group, 1, 1-6.

Blake, S. \& Fay, J.M. (1997) Seed production by Gilbertiodendron dewevrei in the Nouabalé-Ndoki National Park, Congo, and its implications for large mammals. Journal of Tropical Ecology, 14, 885-891.

Blancou, L. (1958) The African Buffalos. African Kingdom, 61(2), 56-61.

Buckland, S. (1993) Distance Sampling: Estimating Abundance of Biological Populations. Chapman \& Hall, London and New York.

Chamberlan, C., Maurois, C. \& Maerechal, C. (1995) Etude mammalogique dans le Parc National d'Odzala. Programme ECOFAC, Composante Congo.

Crook, J.H. (1970) Social organisation and environment; aspects of contemporary social ethology. Animal Behaviour, 18, 197-209.

Dorst, J. \& Dandelot, P. (1972) A Field Guide to the Larger Mammals of Africa. Collins, London.

Estes, R.D. (1991) The Behavior Guide to African Mammals: Including Hoofed Mammals, Carnivores, and Primates. University of California Press, California.

Grubb, P. (1972) Variation and incipient speciation in the African buffalo. Zeitschrift fuer Saeugetierkunde, 37, 121-144.

Hilton-Taylor, C. (compiler) (2000) 2000 IUCN Red List of Threatened Species. IUCN, Gland, Switzerland and Cambridge, UK.

Kingdon, J. (1997) The Kingdon Field Guide to African Mammals. Academic Press, London.

Leonard, J. (1951) Contribution a l'etude de la vegetation des bains d'elephants au Congo Belge. Le RhynchosporetoCyperetum longibracteato. Bulletin de la Societe Royale de Botanique de Belgique, 84, 13-27.
Letousey, R. (1968) Etude Phytogéographique du Cameroun. Encyclopédie Biologique LXIX, Lechevalier, Paris.

Maisels, F. (1996) Synthesis of Information Concerning the Parc National d'Odzala, Republic of Congo. Projet ECOFAC Composante Congo.

Molloy, L.M. (1997) Forest buffalo, Syncerus caffer nanus, and burning of savannas at Lope Reserve, Gabon. Masters thesis, University of Florida, USA.

NNP (2001) Management Plan for the Nouabale-Ndoki National Park, 2001-2006. Ministère de l'Economie Forestière Chargé de la Pêche et des Ressources Halieutiques. Republique du Congo.

Prins, H.H.T. (1996) Ecology and Behaviour of the African Buffalo. Chapman and Hall, London.

Prins, H.H.T. \& Reitsma, J.M. (1989) Mammalian biomass in an Africana equatorial rain forest. Journal of Animal Ecology, 58, 851-861.

Rollet, B. (1964) Introduction à l'Inventaire Forestière du NordCongo. Volume II. Annexes et Illustrations. Rapport 1782, FAO, Rome.

Sinclair, A.R.E. (1977) The African Buffalo. University of Chicago Press, Chicago.

Turkalo, A. \& Fay, J.M. (1995) Studying elephants by direct observation: preliminary results from the Dzanga Clearing, Central African Republic. Pachyderm, 20, 45-54.

Vanleeuwe, H., Cajani, S. \& Gautier-Hion, A. (1998) Large mammals at forest clearings in the Odzala National Park, Congo. Review Ecologique (Terre et Vie), 53, 171-180.

Walsh, P. \& White, L.J.T. (1999) What it will take to monitor forest elephant populations. Conservation Biology, 13, 1194-1202.

Weins, J.A. (1977) On competition and variable environments. American Naturalist, 65, 590-97.

Western, D. (1975) Water availability and its influence on the structure and dynamics of a savannah large mammal community. East African Wildlife Journal, 13, 265-286.

White, L.J.T. (1992) Vegetation history and logging disturbance: effects on rain forest mammals in the Lope Reserve, Gabon (with special emphasis on elephants and apes). $\mathrm{PhD}$ Thesis, University of Edinburgh, Edinburgh, UK.

\section{Biographical sketch}

Stephen Blake is currently a PhD candidate in the Institute of Cell, Animal and Population Biology at the University of Edinburgh, and a Visiting Scholar at the Centre for Environmental Research and Conservation, Columbia University, New York. For the last 8 years he has worked as a Research Fellow for the Wildlife Conservation Society, based in the Nouabalé-Ndoki National Park, Congo. He recently finished a three year research project studying forest elephant ecology for conservation applications, which also forms the basis of his thesis. 